\title{
Gene expression profiling identifies liver $X$ receptor alpha as an estrogen-regulated gene in mouse adipose tissue
}

\author{
L Lundholm¹, S Movérare ${ }^{2}$, K R Steffensen ${ }^{1}$, M Nilsson$^{1}$, M Otsuki ${ }^{1}$, C Ohlsson², \\ J-Å Gustafsson ${ }^{1}$ and $\mathrm{K}$ Dahlman-Wright ${ }^{1}$
}

${ }^{1}$ Department of Biosciences at Novum, Karolinska Institutet, SE-141 57 Huddinge, Sweden

2Department of Internal Medicine, Division of Endocrinology, Sahlgrenska University Hospital, SE-413 45 Göteborg, Sweden

(Requests for offprints should be addressed to L Lundholm; Email: lovisa.lundholm @ biosci.ki.se)

\begin{abstract}
Estrogens reduce adipose tissue mass in both humans and animals. The molecular mechanisms for this effect are, however, not well characterized. We took a gene expression profiling approach to study the direct effects of estrogen on mouse white adipose tissue (WAT). Female ovariectomized mice were treated for 10,24 and $48 \mathrm{~h}$ with $17 \beta$-estradiol or vehicle. RNA was extracted from gonadal fat and hybridized to Affymetrix MG-U74Av2 arrays. 17 $\beta$-Estradiol was shown to decrease mRNA expression of liver $\mathrm{X}$ receptor (LXR) $\alpha$ after $10 \mathrm{~h}$ of treatment compared with the vehicle control. The expression of several LXR $\alpha$ target genes, such as sterol regulatory element-binding protein 1c, apolipoprotein E, phospholipid transfer protein, ATP-binding cassette A1 and ATP-binding cassette G1, was similarly decreased. We furthermore identified a $1.5 \mathrm{~kb} \operatorname{LXR} \alpha$ promoter fragment that is negatively regulated by estrogen. Several genes involved in lipogenesis and lipolysis were identified as novel targets that could mediate estrogenic effects on adipose tissue. Finally, we show that ER $\alpha$ is the main estrogen receptor expressed in mouse white adipose tissue (WAT) with mRNA levels several hundred times higher than those of ER $\beta$ mRNA.
\end{abstract}

Journal of Molecular Endocrinology (2004) 32, 879-892

\section{Introduction}

The prevalence of obesity is rapidly increasing in the western world (Kuczmarski et al. 1994). Obesity is associated with an increased risk of several diseases, such as type 2 diabetes, cardiovascular disease and cancer in breast, prostate, endometrium, colon and gallbladder (Bray 2002). Obesity is the result of increases in adipocyte number and size (Faust et al. 1978). Adipocyte size is determined by the balance between lipid synthesis (lipogenesis) and lipid breakdown (lipolysis) (Prins \& O'Rahilly 1997). Lipogenesis, which involves fatty acid synthesis and subsequent triglyceride (TG) synthesis, occurs in both adipose tissue and liver (Eckel 1989). Lipolysis is the hydrolysis of TG, stored in adipocytes, to free fatty acids and glycerol (Langin et al. 1996). When a critical adipocyte size is reached, further fat accumulation causes an increase in adipocyte number (Faust et al. 1978).

Women generally have more body fat than men and a higher proportion of fat in the glutealfemoral region, the so-called gynoid fat distribution (Blaak 2001). Men generally have more body fat in the abdominal (visceral or central) region, which is called an android fat distribution (Blaak 2001). After menopause, women accumulate more intraabdominal fat and therefore obtain an increased central adiposity (Poehlman 2002). In particular, this central distribution of body fat is a powerful and independent predictor of disease (Poehlman 2002).

Estrogens have important effects on many tissues in the body, among them adipose tissue (Mueller \& Korach 2001). Estrogen could influence adipose 
tissue mass by both central and peripheral effects. Regulation via the central nervous system includes behavioral regulation of feeding and physical activity. Peripheral effects are exerted directly on the adipose tissue. A correlation between estrogen and adipose tissue mass has been seen in both humans and rodents (Heine et al. 2000). An increased adipose mass is seen in women after menopause when estrogen levels decrease, while estrogen replacement therapy decreases adipose mass (Tchernof et al. 1998). Ovariectomy and estrogen treatment in rodents have similar effects on adipose tissue to those seen in humans (Wade \& Gray 1979). Estrogen reduces food intake, which is postulated to occur partly via increased cholecystokinin-signaling and negative feedback on meal size (Geary 2001). There are also reports on increased running-wheel activity in estrogentreated mice, primarily mediated through estrogen receptor (ER) $\alpha$ (Ogawa et al. 2003). Estrogens are also known to decrease adipose tissue mass by increasing lipolysis (Lincova et al. 1984, Tomita et al. 1984), but the molecular mechanisms for this phenomenon are still unclear. Furthermore, postmenopausal women have reduced energy expenditure (Poehlman 2002).

Estrogen exerts its effects via two nuclear receptors, $\mathrm{ER} \alpha$ and $\mathrm{ER} \beta$ (Nilsson et al. 2001). The receptors function as ligand-dependent transcription factors that bind to estrogen response elements (EREs) or, for example, in association with fos and jun, to activator protein 1 (AP-1) sites in target gene promoters (Nilsson et al. 2001). ER $\alpha$ mRNA and protein expression (Price \& O'Brien 1993, Mizutani et al. 1994) and ER $\beta$ mRNA expression (Crandall et al. 1998, Pedersen et al. 2001) have been detected in human adipose tissue. In mouse and rat adipose tissue, estrogen receptors have been detected by estradiol-binding (Seiki et al. 1978, Wade \& Gray 1978, Haslam \& Shyamala 1981). However, to our knowledge, the relative levels of $\mathrm{ER} \alpha$ and $\beta$ have not been reported.

Knockout mouse models have shed light on the role of estrogen and its receptors in rodent obesity. Mice that lack aromatase (ArKO mice) are unable to synthesize endogenous estrogen and display an obese phenotype (Jones et al. 2000). A similar phenotype is observed in mice lacking $\mathrm{ER} \alpha$, but not in mice lacking $\mathrm{ER} \beta$, showing that $\mathrm{ER} \alpha$ is the major mediator of the down-sizing effects of estrogen on mouse fat mass (Heine et al. 2000,
Ohlsson et al. 2000). In addition, $\operatorname{ER} \beta$ has been shown to have anorectic effects mediated via the central nervous system (Liang et al. 2002b). However, in another report, ER $\beta$ was indicated to have opposite effects to ER $\alpha$, as shown by decreased fat mass in ER $\alpha$ knockout (ERKO) mice following ovariectomy (Naaz et al. 2002).

Earlier reports have shown some mechanisms by which estrogen affects metabolism. Estrogen increases hormone-sensitive lipase, which is the rate-limiting enzyme in lipolysis (Palin et al. 2003). Estrogen decreases lipoprotein lipase (LPL) enzyme activity in humans and animals, which is expected to lead ultimately to a decrease in TG deposition in fat cells (Homma et al. 2000, Yamaguchi et al. 2002). Estrogen also represses the activity of hepatic lipase, an enzyme that hydrolyzes TG and phospholipids in lipoproteins, resulting in an increase in high-density lipoprotein (HDL) cholesterol (Jones et al. 2002).

To understand the effects of estrogen in relation to metabolic disease, we have begun to characterize its effects on adipose tissue at the molecular level. In this study, we use gene expression profiling to determine estrogen-regulated genes in mouse white adipose tissue (WAT).

\section{Materials and methods}

\section{Animals}

For determination of $\operatorname{ER} \alpha$ and $\operatorname{ER} \beta$ expression levels, 11-week-old female C57BL/6 wild-type mice were ovariectomized or sham-operated. The animals were kept on soy-free diet for 1 week before they were killed at 13 weeks of age. Gonadal WAT and interscapular brown adipose tissue (BAT) were collected and stored at $-80^{\circ} \mathrm{C}$.

For microarray experiments, 8-week-old female C57BL/6 mice were ovariectomized. After recovery for 2 weeks, the mice were injected (subcutaneously) with $2 \cdot 3 \mu \mathrm{g} /$ mouse of $17 \beta$-estradiol (E2) and killed 10, 24 or $48 \mathrm{~h}$ after the injection. Control mice received injections of vehicle oil (olive oil, Apoteksbolaget, Göteborg, Sweden). Gonadal WAT and liver were collected and kept at $-80{ }^{\circ} \mathrm{C}$. Arterial blood was sampled and centrifuged to obtain serum, in which E2 levels were measured using a radioimmunoassay monitoring E2 (DiaSorin, Saluggia, Italy) with a sensitivity of $10 \mathrm{pg} / \mathrm{ml}$. All studies were approved by Stockholm 
South Ethical Committee for animal experiments and the ethical committee for animal care at Göteborg University.

\section{Microarray analysis}

\section{RNA preparation and experimental design}

Total RNA was prepared from gonadal WAT $(n=7$ for all groups), using Trizol Reagent as previously described (Chomczynski \& Sacchi 1987). RNA was further purified with the RNeasy Mini Kit (Qiagen, Valencia, CA, USA). RNA samples were pooled into two pools $(n=3$ or 4 per pool) per treatment group. There were vehicle-treated and estradioltreated groups for each time point, generating 12 pools in total. RNA was reverse transcribed into cDNA, in vitro transcribed into cRNA and prepared for DNA microarray analysis according to the Affymetrix Gene Chip Expression Analysis manual (MG-U74Av2 array; Affymetrix, Santa Clara, CA, USA).

\section{Bioinformatics}

The scanned output files were analyzed with Affymetrix Microarray Suite Version 5·0 software. Comparisons were made between two estrogentreated and two vehicle-treated samples, generating four comparisons for each time point, using Affymetrix Data Mining Tool Version 3·0. Filters used for the presented data were as follows. For supplemental data, genes were included if the Affymetrix change algorithm gave increased (I) or decreased (D) calls respectively for all comparisons. Genes absent (A) according to the Affymetrix detection algorithm on both arrays of a comparison have been excluded. Furthermore, the average fold change was $\geqslant 2$. For Table 1, average fold changes are given for genes increased (I) or decreased (D) respectively in at least three out of four comparisons.

\section{Real-time PCR analysis}

Total RNA was prepared as described above. An amount of $1 \mu \mathrm{g}$ of RNA from individual animals was reverse transcribed into cDNA using Reverse Transcription Reagents with random hexamer primers (Applied Biosystems, Foster City, CA, USA). Analysis was performed with the ABI Prism 7700 Sequence Detection System (Applied Biosystems). Primer sequences for apolipoprotein E (apoE), glucose-6-phosphate dehydrogenase $(\mathrm{G} 6 \mathrm{DH})$ and glycerol-3-phosphate acyltransferase (GPAT) (Liang et al. 2002a) and sterol regulatory element-binding protein (SREBP) 1c (Stulnig et al. 2002) have been described previously. Additional primer and probe sequences are shown in Table 2. A SYBR Greenbased protocol was used for apoE, G6PD and GPAT mRNA expression analysis. In this case, PCR products were further analyzed by melting curve analysis to confirm a single product. A TaqMan probe-based protocol was used for all other genes. mRNA levels were calculated by the 'Standard Curve Method' (multiplex reactions, according to instructions in User Bulletin no. 2, Applied Biosystems). mRNA expression levels were normalized to $18 \mathrm{~S}$ rRNA in all studies except for the $\mathrm{ER} \alpha$ and ER $\beta$ expression study, where glyceraldehyde-3phosphate dehydrogenase (GAPDH) was used (Applied Biosystems). In addition, known amounts of mouse ER $\alpha$ and ER $\beta$ (Pettersson et al. 1997) and rat GAPDH (gift from Dr Christine Sadek, Department of Biosciences) plasmids were used as standards to calculate absolute amounts of the receptor mRNAs.

\section{Plasmid constructs}

The mouse liver $\mathrm{X}$ receptor $(\mathrm{LXR}) \alpha-1513 /+1$ promoter fragment was obtained by PCRamplification from a longer promoter fragment, using Taq Polymerase (Roche Diagnostics, Indianapolis, IN, USA) with primers 5'-TTAAT GAGGCGTCATGGGAATTGGAGTTCACA-3' and 5'-GTCAGCGTGGAGTGCGCCGTCGTC CCAAA-3' incorporating MluI and XhoI restriction sites (underlined) respectively. The PCR product was cleaved with the appropriate enzymes and cloned into the pGL3-Basic Vector (Promega, Madison, WI, USA). The sequence of the promoter fragment was verified by DNA sequencing. An expression vector containing mouse $\mathrm{ER} \alpha$ cloned into the pSG5 vector (Stratagene, La Jolla, CA, USA) was used in the cotransfections (Pettersson et al. 1997). Empty pGL3-Basic and pSG5 vectors were used as controls.

\section{Transient transfections}

Mouse hepatoma cells (Hepa) were cultured in DMEM containing $4.5 \mathrm{~g} / \mathrm{l}$ glucose (Invitrogen, Carlsbad, CA, USA) supplemented with 10\% FBS, $100 \mathrm{U}$ penicillin $/ \mathrm{ml}$ and $100 \mu \mathrm{g}$ streptomycin $/ \mathrm{ml}$. A total of 10000 cells/well were seeded in 24-well 
Table 1 Genes involved in metabolism. Average fold changes are given for genes increased or decreased respectively in at least three out of four comparisons. Genes are marked if not changed (NC) in at least three out of

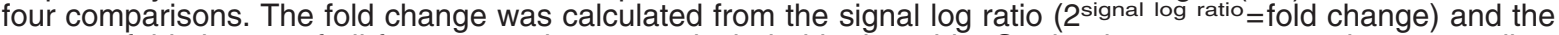
average fold change of all four comparisons was included in the table. Sorting into groups was done according to the references included in the table. The accession numbers were accessed from www.affymetrix.com, using the Netaffx Analysis Center (Liu et al. 2003). \#Genes mentioned in the text. *Genes increased from absent to present or decreased from present to absent, which could give less accurate fold changes.

\section{Average fold change}

\section{Name}

\section{Genes increased in} adipogenesis/lipogenesis adipocyte complement related protein/adiponectin\# adipsin

adrenergic receptor, beta $3^{\#}$

adrenergic receptor, beta $3^{\#}$

adrenergic receptor, beta $3^{\#}$

angiotensinogen

ATP citrate lyase

CCAAT/enhancer binding protein (C/EBP), alpha ${ }^{\#}$

CCAAT/enhancer binding protein (C/EBP), beta

CCAAT/enhancer binding protein (C/EBP), delta

fatty acid binding protein 4 , adipocyte/aP2 fatty acid synthase ${ }^{\#}$

glucose-6-phosphate dehydrogenase X-linked"

glycerol phosphate dehydrogenase 1 , mitochondrial

glycerol-3-phosphate acyltransferase, mitochondrial\#

insulin I

insulin I

insulin II

lipoprotein lipase\#

lactate dehydrogenase 2 , B chain\#

liver $\mathrm{X}$ receptor alpha\#

glucocorticoid receptor

peroxisome proliferator activated receptor gamma

phosphoenolpyruvate carboxykinase 1 , cytosolic (PEPCK)

pyruvate carboxylase ${ }^{\#}$

pyruvate carboxylase ${ }^{\#}$

pyruvate carboxylase ${ }^{\#}$

retinol binding protein 4 , plasma\#

signal transducer and activator of transcription $1^{\#}$

stearoyl-coenzyme A desaturase 1

stearoyl-coenzyme A desaturase 2

sterol regulatory element binding factor 1 \#
Accession no.

$10 \mathrm{~h}$

NM_009605

NM_013459

X72862

X72862

X72862

NM_007428

AW121639

NM_007678

NM_009883

NM_007679

NM_024406

X13135

NM_008062

NM_010274

NM_008149

NM_008386

NM 008386

NM_008387

NM_008509

NM 008492

NM_013839

NM_008173

NM_011146

NM_011044

NM_008797

NM 008797

NM 008797

U63146

NM_009283

NM_009127

NM_009128

NM_011480

$10 \mathrm{~h}$

$24 \mathrm{~h}$

$24 \mathrm{~h}$

$48 \mathrm{~h}$

Reference

Soukas et al. 2001)

Soukas et al. 2001)

(Collins et al 2001,

Nadler et al. 2000)

(Collins et al. 2001,

Nadler et al. 2000)

(Collins et al. 2001,

Nadler et al. 2000)

(Nadler et al. 2000)

(Shimomura et al. 1999)

(Soukas et al. 2001)

(Soukas et al. 2001)

(Soukas et al. 2001)

$\mathrm{NC} \quad \mathrm{NC} \quad \mathrm{NC}$

NC NC

$2.4 \quad 1.6$

(Soukas et al. 2001)

(Shimomura et al. 1999)

(Shimomura et al. 1999)

NC

(Nadler et al. 2000)

$1.5 \quad 1.4$

(Shimomura et al. 1999)

(Kersten 2001)

(Kersten 2001)

(Kersten 2001)

NC (Yamaguchi et al. 2002)

(Nadler et al. 2000)

(Schultz et al. 2000)

$\begin{array}{rrr}N C & -2.3 & \\ -1.6 & -1.2 \\ & N C & N C\end{array}$

(Rosen \& Spiegelman 2000)

(Soukas et al. 2001)

NC NC

(Nadler et al 2000)

$-1.8 \quad 1.7$

$-1.9 \quad 1.4$

$-1.7$

$-1.5$

$-2 \cdot 0$

NC

NC

NC

(Nadler et al. 2000)

(Nadler et al. 2000)

(Nadler et al. 2000)

(Nadler et al. 2000)

(Soukas et al. 2001

NC NC

$\mathrm{NC} \quad \mathrm{NC}$

NC

NC

NC
(Soukas et al. 2001)

(Soukas et al. 2001)

(Soukas et al. 2001) 
Table 1 Continued

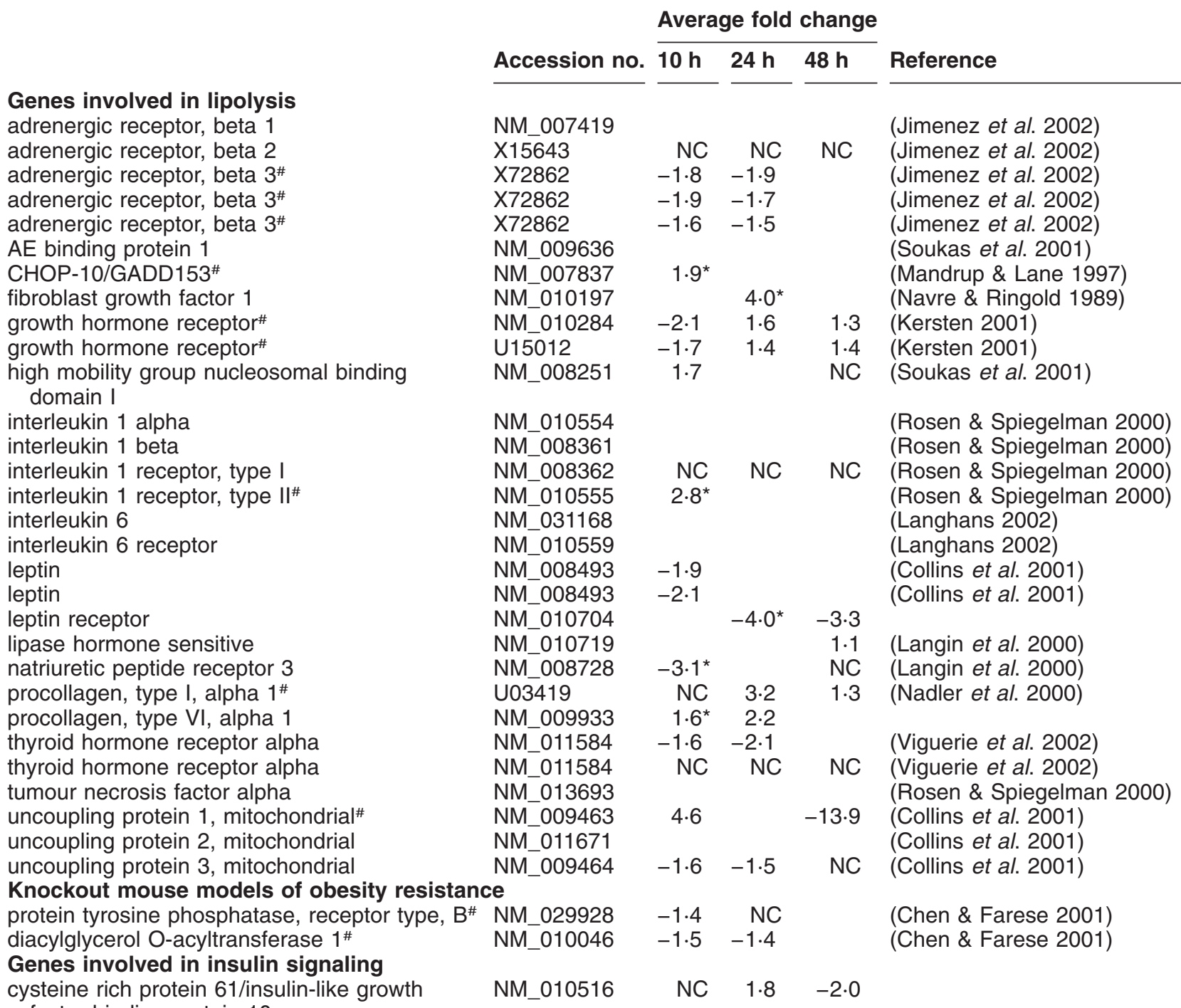

factor binding protein 10

ESTs, highly similar to IRS2_mouse insulin receptor substrate-2 (IRS-2)(4PS)[M. musculus]

insulin receptor

insulin receptor substrate 1

insulin-like growth factor 1

insulin-like growth factor 1

insulin-like growth factor 2

insulin-like growth factor 2

insulin-like growth factor 2 receptor\#

insulin-like growth factor binding protein 1

insulin-like growth factor binding protein 1

insulin-like growth factor binding protein 2 insulin-like growth factor binding protein 3 insulin-like growth factor binding protein 4 insulin-like growth factor binding protein 4

\section{AF090738}

NM_010568

NM_010570

NM_010512

NM_010512

NM_010514

NM 010514

NM_010515

NM_008341

NM_008341

NM_008342

NM_008343

NM 010517

NM_010517
NC

$\mathrm{NC}$

$1 \cdot 4$

$-1.4 \quad-1.7 \quad N C$

NC

$-3 \cdot 4^{*}$

$\begin{array}{lll}-1.4 & 1.5 \quad \mathrm{NC}\end{array}$

www.endocrinology.org 
Table 1 Continued

insulin-like growth factor binding protein 5 insulin-like growth factor binding protein 6 insulin-like growth factor I receptor\#

\section{Proteins related to lipoproteins} apolipoprotein A-I apolipoprotein A-II apolipoprotein A-IV apolipoprotein C-I apolipoprotein C-II apolipoprotein C-IV apolipoprotein D apolipoprotein $\mathrm{E}^{\#}$ low density lipoprotein receptor ${ }^{\#}$ low density lipoprotein receptor-related protein I nuclear receptor subfamily 2 , group

F, member 2/COUP-TF2/Apo (A1) regulatory protein 1 (ARP1)

very low density lipoprotein receptor

Other genes

ATP-binding cassette, sub-family A, member 1 $(\mathrm{ABCA} 1)^{\#}$

ATP-binding cassette, sub-family A, member 1 $(\mathrm{ABCA} 1)^{\#}$

ATP-binding cassette, sub-family $\mathrm{G}$, member 1 (ABCG1)\#

CCAAT/enhancer binding protein (C/EBP), gamma

cytochrome P450, 7a1

fatty acid coenzyme A ligase, long chain $2^{\#}$ glucose regulated protein/phospholipase C-alpha

isocitrate dehydrogenase 1 (NADP+), soluble lipase, hepatic

nuclear receptor coactivator 1/SRC-1

peroxisome proliferative activated receptor, gamma, coactivator 1 (PGC1)

peroxisome proliferator activated receptor alpha phospholipid transfer protein ${ }^{\#}$
Average fold change

\begin{tabular}{|c|c|c|c|c|}
\hline Accession no. & $10 \mathrm{~h}$ & $24 \mathrm{~h}$ & $48 \mathrm{~h}$ & Reference \\
\hline $\begin{array}{l}\text { NM_010518 } \\
\text { NM_008344 }\end{array}$ & $\mathrm{NC}$ & $\begin{array}{l}1.9 \\
2.4\end{array}$ & $\mathrm{NC}$ & \\
\hline AF056187 & & $-3 \cdot 0$ & $-2 \cdot 3$ & \\
\hline
\end{tabular}

NM_009692

NM_013474

NM_007468

NM_007469

NM_009695

NM_007385

NM_007470

NM_009696

NM_010700

NM_008512

NM_009697

$\begin{array}{rrr}-1.7 & \mathrm{NC} & \mathrm{NC} \\ & 1.7 & \mathrm{NC} \\ \mathrm{NC} & 1.7 & \mathrm{NC} \\ \mathrm{NC} & -1.5 & \end{array}$

NC

NM_013703

NM $013454-1.9$

NM_013454 $-1.8 \quad$ NC

NM $009593 \quad-1 \cdot 2^{*} \quad$ NC

AB012273 NC NC

NM_007824

NM_007981

NM_007952

$\begin{array}{lll}-1.5 & -1.6 & 1.3\end{array}$

$2 \cdot 0 \quad 1.4$

NM_010497

NC $\quad 2 \cdot 1$

NM_008280

NM_010881

NM_008904

NM_011144

NM_011125 $-1.7 \quad$ NC NC plates $20 \mathrm{~h}$ before transfection in phenol red-free, high-glucose DMEM (Invitrogen) supplemented with 10\% dextran-coated charcoal-treated FBS, $2 \mathrm{mM}$ L-glutamine, $1 \mathrm{mM}$ sodium pyruvate, $100 \mathrm{U}$ penicillin $/ \mathrm{ml}$ and $100 \mu \mathrm{g}$ streptomycin/ml. Mouse preadipocyte cells (3T3-L1K) were cultured in DMEM containing $4.5 \mathrm{~g} / \mathrm{l}$ glucose (Invitrogen) supplemented with $10 \%$ calf serum, $2 \mathrm{mM}$ L-glutamine, $100 \mathrm{U}$ penicillin/ml and $100 \mu \mathrm{g}$ streptomycin $/ \mathrm{ml}$. A total of 20000 cells/well were seeded in 24-well plates $16 \mathrm{~h}$ before transfection in the same charcoal-treated FBS-containing media as described above for Hepa. The $-1513 /+1$ LXR $\alpha$ promoter construct or empty pGL3-Basic vector (both expressing firefly luciferase as a reporter gene) was cotransfected with $\mathrm{ER} \alpha$ or empty pSG5 vector, using Lipofectamine 2000 in Opti-Mem I Reduced Serum Medium according to the standard protocol (Invitrogen). A plasmid-expressing Renilla luciferase under control of the thymidine kinase promoter (pRL-TK, Promega) was included as a positive control to exclude a general effect on transcription and/or translation of estrogen in the transfected cells. The medium was changed after $5 \mathrm{~h}$ to 
Table 2 Real-time PCR primers and probe sequences for $m E R \alpha, m E R \beta$ and $m L X R \alpha$

mER $\boldsymbol{\alpha}$ (NM_007956)

Over exon-exon boundary

mERß (NM_010157)

Over exon-exon boundary

$\operatorname{mLXR\alpha }($ AJ132599)

Over exon-exon boundary
Forward primer

Reverse primer

Probe

Forward primer

Reverse primer

Probe

Forward primer

Reverse primer

Probe

\author{
5'-GTGCCTGGCTGGAGATTCTG-3' \\ 5'-GAGCTTCCCCGGGTGTTC-3' \\ 5'-TGATTGGTCTCGTCTGGCGCTCC-3' \\ 5'-CAGTCCGTCTGGCCAACCT-3' \\ 5'-ACCACATTTTTTGCACTTCA-3' \\ 5-'TGTTCCATGCCCTTGTTACTGATGTGCCT-3' \\ 5'-TCGCAAATGCCGCCA-3' \\ 5-'TCAAGCGGATCTGTTCTTCTGA-3' \\ 5'-AGCACACACTCCTCCСTCATGCCTG-3'
}

charcoal-treated FBS-containing media with $10 \mathrm{nM}$ E2 or vehicle $(99 \cdot 5 \% \mathrm{EtOH})$. Cells were harvested $24 \mathrm{~h}$ after transfection, and firefly and Renilla luciferase activities were determined by the Dual-Luciferase Reporter Assay System (Promega) according to the manufacturer's instructions.

\section{Results}

\section{$E R \alpha$ and ER $\beta$ mRNA expression in mouse adipose tissue}

mRNA levels of ER $\alpha$ and ER $\beta$ are shown in Fig. $1 \mathrm{~A}$ and $\mathrm{B}$ respectively. $\mathrm{ER} \alpha$ levels in WAT were approximately double those in BAT for both sham-operated and ovariectomized mice (Fig. 1A). Low levels of ER $\beta$ mRNA could be detected in mouse adipose tissue by quantitative real-time PGR; however, ER $\alpha$ is the main ER expressed in both WAT and BAT of mouse (Fig. 1G).

\section{Gene expression profiling identifies estrogen-regulated genes in mouse WAT}

To identify estrogen-regulated signaling networks in mouse WAT, we treated mice with a single injection of E2. E2 levels were highest after $10 \mathrm{~h}$ and decreased with time (Fig. 2A). Gene expression profiles were analyzed after 10, 24 and $48 \mathrm{~h}$ treatment. An overview of the number of estrogen-regulated genes after the different treatment times is shown in Fig. 2B. The number of changed genes is highest after $24 \mathrm{~h}$.

The microarray results were confirmed with real-time PCR (Fig. 3). Two genes with increased and two genes with decreased expression were selected for the confirmation. Genes involved in adipogenesis or lipogenesis and lipolysis were identified from the literature and are presented in Table 1. Genes known to be increased in lipogenesis or adipogenesis, and that were decreased following estrogen treatment, are likely to play a role in the mechanism of estrogenic decrease of adipose tissue mass. CCAAT/enhancer-binding protein $(\mathrm{C} / \mathrm{EBP} \alpha)$, signal transducer and activator of transcription 1 (STAT1), retinol-binding protein (RBP) and pyruvate carboxylase were all decreased after $10 \mathrm{~h}$ treatment, as were lactate dehydrogenase-B and adiponectin after $24 \mathrm{~h}$.

Genes known to be repressed in lipogenesis/ adipogenesis or increased during lipolysis might also play a role in decreasing adipose tissue mass. CHOP-10/GADD153 and uncoupling protein 1 (UCP1) were increased after $10 \mathrm{~h}$, and alpha-1 type I procollagen after $24 \mathrm{~h}$. Some receptors for lipolytic hormones were also increased, interleukin 1 receptor type II after $10 \mathrm{~h}$ and growth hormone receptor after 24 and $48 \mathrm{~h}$, although the growth hormone receptor was decreased first (after $10 \mathrm{~h}$ ).

Several other metabolism-associated genes were found to be under estrogenic control, such as low-density lipoprotein receptor (LDLR), fatty acid coenzyme A ligase long chain 2, insulin-like growth factor I receptor and insulin-like growth factor 2 receptor.

Many knockout mouse models exist with a phenotype of leanness and obesity resistance (Chen \& Farese 2001). Two of the genes knocked out in the leanness models, protein tyrosine phosphatase $1 \mathrm{~B}$ and acyl-CoA:diacylglycerol acyltransferase (DGAT), decreased in expression after $10 \mathrm{~h}$, and after 10 and $24 \mathrm{~h}$ of treatment respectively.

Several other regulated genes were found in this study. Many genes with increased expression following E2 administration are involved in cell adhesion, most of them encoding procollagens of 

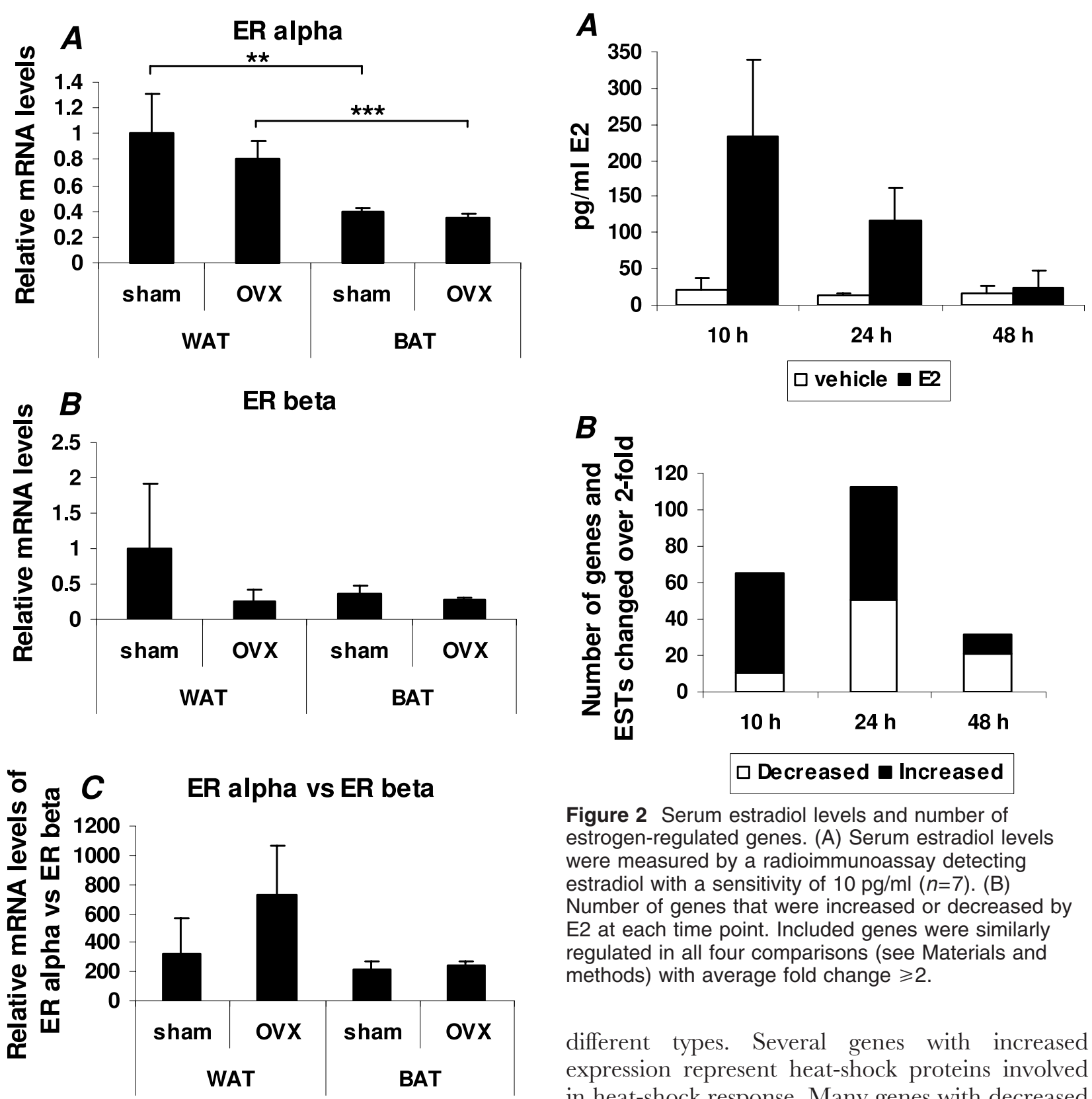

\section{$\square$ Decreased $\square$ Increased}

Figure 2 Serum estradiol levels and number of estrogen-regulated genes. (A) Serum estradiol levels were measured by a radioimmunoassay detecting estradiol with a sensitivity of $10 \mathrm{pg} / \mathrm{ml}(n=7)$. (B) Number of genes that were increased or decreased by E2 at each time point. Included genes were similarly regulated in all four comparisons (see Materials and methods) with average fold change $\geqslant 2$.

different types. Several genes with increased expression represent heat-shock proteins involved in heat-shock response. Many genes with decreased expression are involved in transcription regulation, including some SRY-box containing genes.

expression in mouse WAT and BAT. ER mRNA expression in WAT and BAT in sham-operated and ovariectomized (OVX) 13-week-old female C57BL/6 mice $(n=4)$ was analyzed with real-time PCR. (A) ER $\alpha$ mRNA levels, (B) ER $\beta$ mRNA levels and (C) relative expression of ER $\alpha$ and $E R \beta$. Results presented are means \pm standard deviation normalized to GAPDH, with the first sample set to 1 . In (C), known amounts of plasmids were used as standards in the calculation of the absolute amounts of receptor mRNAs. Statistical significance relies on Student's $t$-test: ${ }^{\star \star} P<0.01$; ${ }^{\star \star \star} P<0.001$.

\section{LXR $\alpha$ is a target gene for estrogen in WAT and liver}

Interestingly, one gene found to be decreased $10 \mathrm{~h}$ after estrogen treatment was the nuclear receptor LXR $\alpha$. LXRs have been shown to play important roles in lipid and cholesterol metabolism (Steffensen et al. 2002). Recently, LXR double-knockout mice 

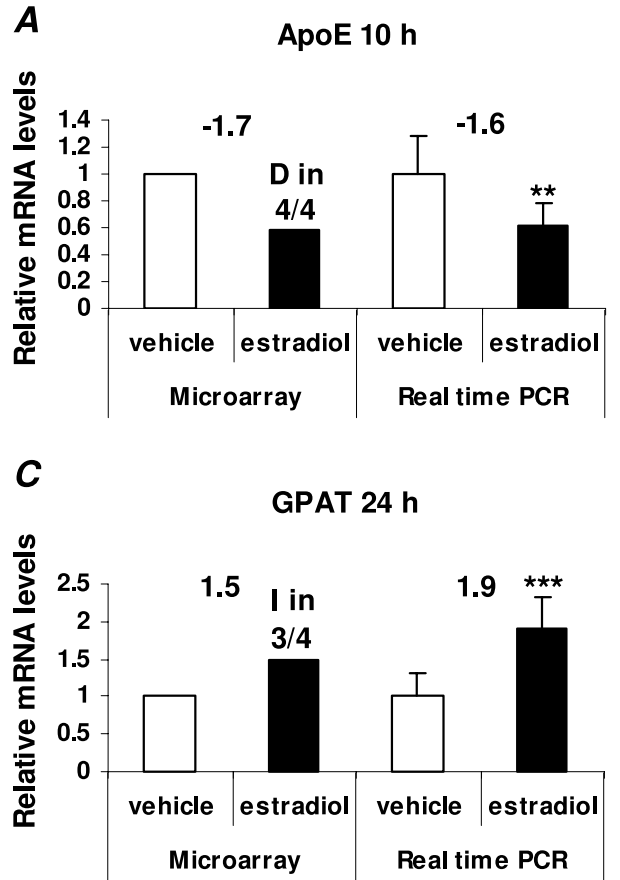

$\boldsymbol{B}$

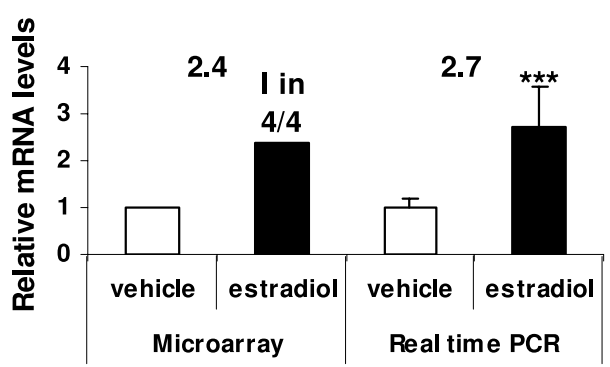

$\boldsymbol{D}$

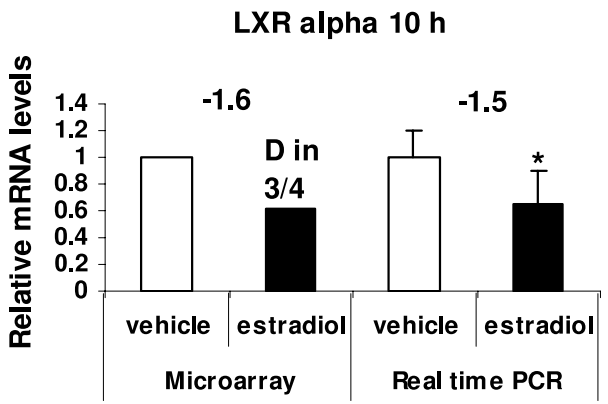

Figure 3 Confirmation of Affymetrix results by real-time PCR. Estrogen regulation of (A) apolipoprotein E (apoE), (B) glucose-6-phosphate dehydrogenase (G6PD), (C) glycerol-3-phosphate acyltransferase (GPAT) and (D) liver X receptor (LXR) $\alpha$ was confirmed at different time points. RNA from individual mice (the same mice as for the gene expression profiling) was used $(n=7)$. Results presented are means \pm standard deviation normalized to $18 \mathrm{~S}$, with the first sample set to 1 . $D=$ decreased, I=increased in three or four out of four comparisons (3/4 or $4 / 4$, respectively); however, all comparisons were used for the calculation of average fold change. The numbers included are fold changes for the E2 vs vehicle treatments. Statistical significance relies on Student's $t$-test: ${ }^{*} P<0.05 ;{ }^{* *} P<0.01 ;{ }^{* *} P<0.001$.

Table 3 Regulation of LXR $\alpha$ target genes in fat as determined by Affymetrix analysis. Regulation is indicated with the average fold change as in Table 1, and time point. Numbers in parenthesis are the numbers of comparisons.

References for target gene regulation by LXR $\alpha$ are included in the reference column.

\begin{tabular}{|c|c|c|c|}
\hline Name & Regulation & Function (Edwards et al. 2002) & Reference \\
\hline SREBP-1C & $\begin{array}{l}-1.610 \text { h (3/4); } \\
-1.424 \text { h }(4 / 4)\end{array}$ & Fatty acid synthesis & (Repa et al. 2000) \\
\hline Apolipoprotein E & $-1.710 \mathrm{~h}(4 / 4)$ & Clearance of cholesterol & (Laffitte et al. 2001) \\
\hline $\begin{array}{l}\text { Phospholipid transfer } \\
\text { protein }\end{array}$ & -1.710 h $(4 / 4)$ & HDL metabolism & (Cao et al. 2002) \\
\hline $\mathrm{ABCA} 1$ & $-1.910 \mathrm{~h}(4 / 4)$ & Efflux of phospholipid and/or cholesterol & (Costet et al. 2000) \\
\hline ABCG1/ABC8 & $-1 \cdot 210 \mathrm{~h}(4 / 4)$ & Efflux of phospholipid and/or cholesterol & (Venkateswaran et al. 2000) \\
\hline
\end{tabular}

were reported to have significantly decreased WAT and BAT (Juvet et al. 2003). A 10-h estrogen treatment also repressed the mRNA levels of several known target genes normally upregulated by LXR $\alpha$, such as sterol regulatory elementbinding protein 1c (SREBP-1c), apolipoprotein E
(apoE), phospholipid transfer protein (PLTP), ATP-binding cassette (ABG) Al and ABGG1 (Table 3). The regulation of LXR $\alpha$ and SREBP-1c observed with the Affymetrix gene chips was confirmed using real-time PCR analysis (Fig. 4A and $\mathrm{B})$. LXR $\beta$ was not regulated by estrogen in this 

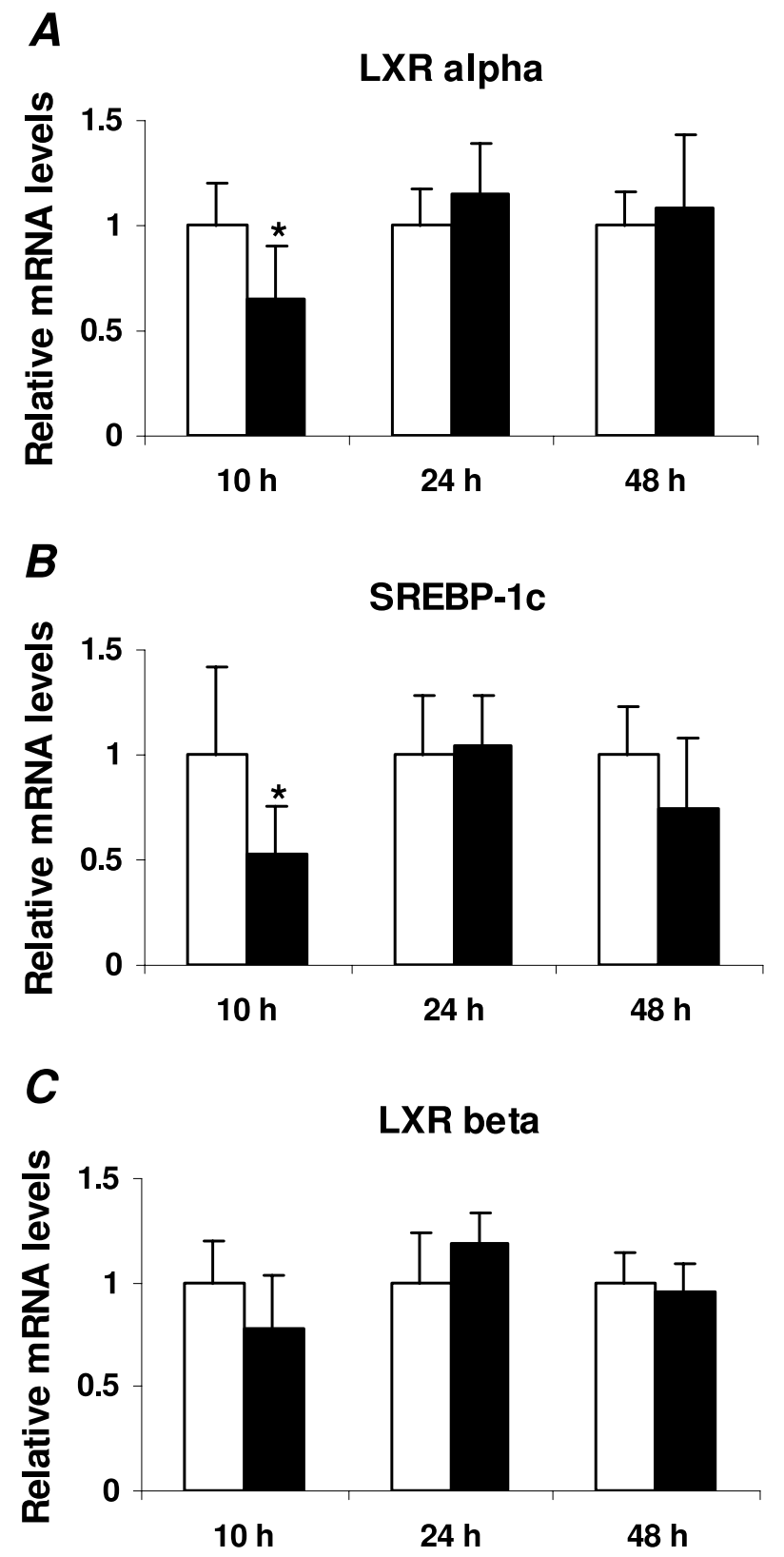

$\square$ vehicle $\square \mathrm{E2}$

Figure $4 \mathrm{LXR} \alpha$ and SREBP-1c, but not LXR $\beta$, mRNA levels were decreased after $10 \mathrm{~h}$ of estrogen treatment in adipose tissue. (A) $L X R \alpha$ mRNA levels, (B) SREBP-1c mRNA levels and (C) LXR $\beta$ mRNA levels. RNA from individual mice (the same mice as for the gene expression profiling) was used $(n=7)$. Results presented are means \pm standard deviation normalized to $18 \mathrm{~S}$, with the first sample set to 1 . Statistical significance relies on Student's $t$-test: ${ }^{\star} P<0.05$.

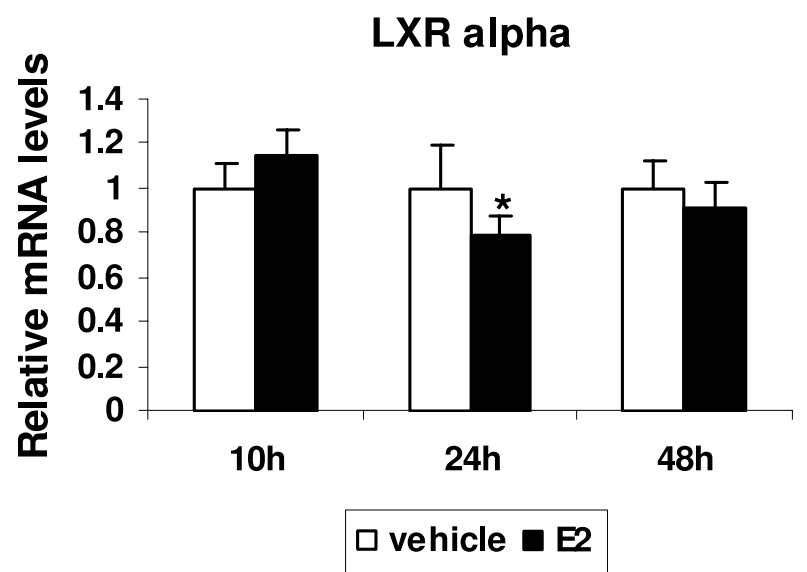

Figure $5 \mathrm{LXR} \alpha \mathrm{mRNA}$ is decreased after $24 \mathrm{~h}$ of estrogen treatment in liver. RNA from liver was used, and expression was analyzed by real-time PCR. RNA from individual mice (the same mice as for the gene expression profiling) was used $(n=7)$. Results presented are means \pm standard deviation normalized to $18 \mathrm{~S}$, with the first sample set to 1 . Statistical significance relies on Student's $t$-test: ${ }^{\star} P<0.05$.

system (Fig. 4G). Liver is another target organ for the metabolic effects of estrogen. Interestingly, estrogen decreases mRNA levels of LXR $\alpha$ also in liver after $24 \mathrm{~h}$ of treatment (Fig. 5).

\section{The LXR $\alpha$ promoter is repressed by estrogen}

To determine whether the $\operatorname{LXR} \alpha$ promoter is a direct target for estrogen repression, an approximately $1.5 \mathrm{~kb}$ fragment of the 5 '-flanking region of the mouse LXR $\alpha$ gene (positions -1513 to +1 ), was cloned, as described in Materials and methods (Fig. 6A). The construct was transiently transfected into Hepa cells and 3T3-L1K cells together with an ER $\alpha$ expression plasmid as indicated. Estrogen treatment, in the presence of ER $\alpha$, decreases the activity of the firefly luciferase reporter gene by $60 \%$ in Hepa cells (Fig. 6B) and $77 \%$ in 3T3-L1K cells (Fig. 6C). A positive control was included to exclude a general effect on transcription and/or translation of estrogen in the transfected cells (Fig. 6B-C).

\section{Discussion}

In this paper, we describe the direct effects of estrogens on WAT gene expression. In particular, we demonstrate downregulation of $\operatorname{LXR} \alpha$ and 
several of its target genes after $10 \mathrm{~h}$ of estrogen treatment. Our findings are consistent with a recent report showing estrogen regulation of $\operatorname{LXR} \alpha$ in primary macrophages and leukemic, monocytic THP-1 cells (Kramer \& Wray 2002). However, our report is the first to demonstrate estrogen regulation of LXR $\alpha$ in metabolic tissues. Furthermore, we demonstrate direct downregulation of the LXR $\alpha$ promoter by estrogen. The studied fragment of the LXR $\alpha$ promoter contains one estrogen

\section{$A$}

$-1513 /+1 \mathrm{mLXR}$ promoter in pGL3-Basic

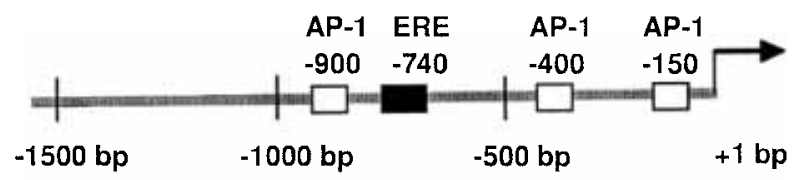

\section{$B$}

\section{Relative luciferase activity in Hepa cells}

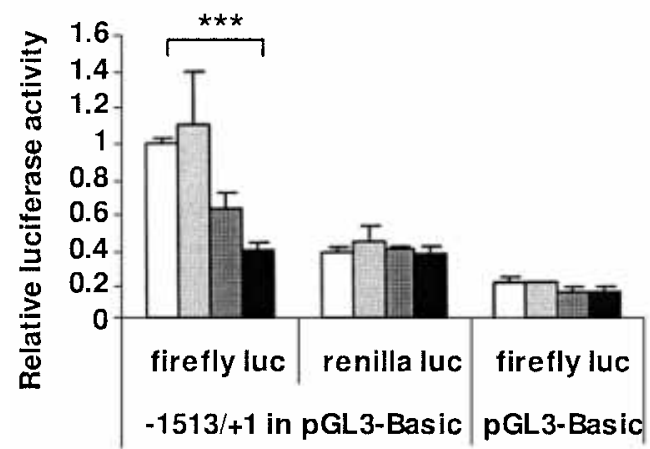

\section{C}

Relative luciferase activity in 3T3-L1K cells

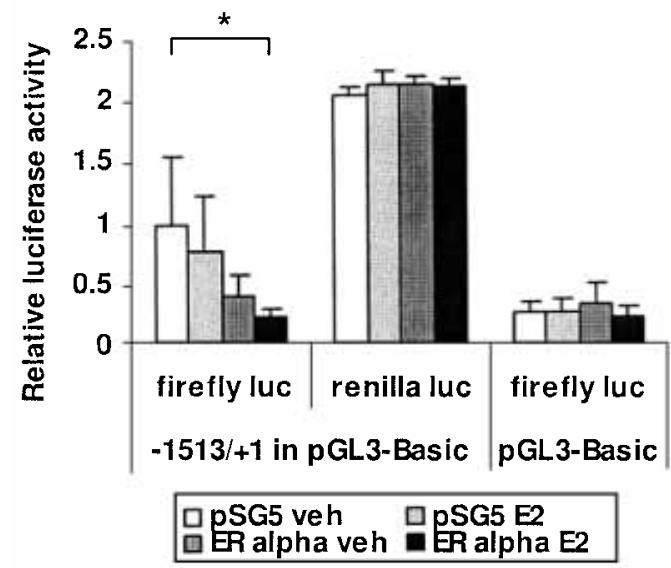

response element (ERE) sequence with deviation from the consensus at three positions, and several AP-1 sites (Fig. 6A). Further studies will be needed to determine whether these sites contribute to the observed downregulation of LXR $\alpha$ by estrogen. Downregulation of LXR $\alpha$ expression was observed only after $10 \mathrm{~h}$ of estrogen treatment. We speculate that levels of estrogen in WAT after $24 \mathrm{~h}$ are insufficient to maintain suppression of the $\operatorname{LXR} \alpha$ promoter.

Estrogen action on adipose tissue could be mediated via $\operatorname{LXR} \alpha$ and its target genes. SREBP-1c activates genes involved in fatty acid synthesis (Repa et al. 2000). SREBP-1c-deficient mice have reduced plasma TGs and reduced mRNA levels of enzymes of fatty acid and TG synthesis (Liang et al. 2002a). Therefore, the decrease in SREBP-1c following estrogen could explain the decrease in amount of adipose tissue seen after estrogen treatment.

Phospholipid transfer protein (PLTP), apoE, ABCA1 and ABCG1 are other target genes of LXR $\alpha$ that were regulated by estrogen in this experiment. There has been one report of a decreased PLTP activity after 71 days of hormone replacement therapy in women (Ulloa et al. 2002). Serum concentration of apoE was decreased by estrogen in prostate cancer patients (Usui et al. 2002) but was also found to be increased by estrogen in brain (Levin-Allerhand et al. 2001). Only two LXR $\alpha$ target genes, fatty acid synthase (FAS) and lipoprotein lipase (LPL), were unchanged according to our criteria for assessing changed expression of genes. For LPL, however,

Figure 6 Estrogen decreases expression from the LXR $\alpha$ promoter in Hepa and 3T3-L1K cells. An amount of $0.2 \mu \mathrm{g} L X R \alpha-1513 /+1$ promoter construct or empty pGL3-Basic vector (expressing firefly luciferase) was cotransfected with $0.05 \mu \mathrm{g}$ ER $\alpha$ or empty pSG5 vector. Amounts of 0.002 or $0.0005 \mu \mathrm{g}$ of a plasmid expressing Renilla luciferase under control of the thymidine kinase promoter were added to the transfections of Hepa and 3T3-L1K cells respectively to exclude a general effect on transcription and/or translation of estrogen in these cells. Cells were treated with vehicle $(99.5 \% \mathrm{EtOH})$ or $10 \mathrm{nM}$ E2. (A) LXR $\alpha$ promoter construct, (B) transfection of Hepa cells and (C) transfection of 3T3-L1K cells. The data presented are relative values based on average luciferase activities and are representative of at least three independent transfections. The first sample is set to 1 . Statistical significance relies on Student's $t$-test: ${ }^{\star} P<0.05 ;{ }^{* \star \star} P<0.001$. 
the regulation by LXR $\alpha$ was observed only in liver and macrophages, not in adipose tissue or muscle (Zhang et al. 2001). Direct regulation of FAS by LXR $\alpha$ has been shown before in HepG2 cells (Joseph et al. 2002).

Several other important genes involved in lipid metabolism were found to be regulated by estrogen in adipose tissue. CGAAT enhancer-binding protein $\alpha(\mathrm{C} / \mathrm{EBP} \alpha)$ is required for differentiation of WAT and fat accumulation (Linhart et al. 2001). $\mathrm{C} / \mathrm{EBP} \alpha$ knockout mice die just after birth due to severe hypoglycemia, but they also fail to accumulate interscapular fat (Wang et al. 1995, Flodby et al. 1996). Since hepatic dysfunction was the major cause of lethality, mice expressing $\mathrm{C} / \mathrm{EBP} \alpha$ exclusively in the liver were generated. These transgenic $\mathrm{C} / \mathrm{EBP} \alpha$ knockout mice survived longer and lacked subcutaneous, perirenal and epididymal WAT already at 7 days of age (Linhart et al. 2001).

Downregulation of $\mathrm{C} / \mathrm{EBP} \alpha$ might play an important part in the mechanism of estrogeninduced decrease in adipose tissue, since, in this study, estrogen treatment decreased $\mathrm{C} / \mathrm{EBP} \alpha$ expression. $\mathrm{C} / \mathrm{EBP} \alpha$ is required for expression of the $\beta 3$-adrenergic receptor during adipogenesis (Dixon et al. 2001). The $\beta 3$-adrenergic receptor was also downregulated after 10 and $24 \mathrm{~h}$ of estrogen treatment. Interestingly, peroxisome proliferator activated receptor (PPAR) $\gamma$ was not regulated in our experiment. This lack of PPAR $\gamma$ regulation was confirmed by real-time PCR (data not shown). Therefore, PPAR $\gamma$ does not appear to be a direct target for estrogen in mouse fat.

One of the genes knocked out in mouse models of obesity resistance, acyl coenzyme A:diacylglycerol transferase, is responsible for the final step in the glycerol phosphate pathway of TG synthesis (Bray 2002). These mice also show increased thermogenesis (Bray 2002). The other knockout gene mentioned which leads to obesity resistance, protein tyrosine phosphatase-1B (PTP-1B), encodes an enzyme that terminates the action of phosphorylated tyrosines in receptors (Bray 2002). The gene has been implicated in insulin resistance, since insulin resistance is reduced in this knockout (Bray 2002).

Several of the regulated genes (Table 1 and data not shown) can serve as positive controls for the identification of estrogen-regulated genes, since they are known to be regulated by estrogen. They include the low-density lipoprotein receptor (LDLR) (Parini et al. 1997), creatine kinase (Somjen et al. 1997) and the SRY-box containing gene 4 (Hunt \& Clarke 1999).

The identification of $\mathrm{ER} \alpha$ as the major ER in adipose tissue is in good agreement with previous findings of obesity in ER $\alpha$ knockout mice, and supports the notion that direct ER $\alpha$-mediated effects of estrogens in adipose tissue decrease adipose mass.

Estrogen is known to affect fat mass in humans. It is possible that SERMs (selective estrogen receptor modulators) specifically targeting adipose tissue might provide therapeutic opportunities for obesity.

In conclusion, we have discovered that LXR $\alpha$ represents an estrogen-regulated pathway in adipose tissue. Several metabolism-associated genes not previously known to be regulated by estrogens were identified as possible mediators of estrogeninduced reduction of adipose tissue, including SREBP-1c and C/EBPa. A large number of other estrogen-regulated genes were identified in mouse adipose tissue.

\section{Acknowledgements}

This work was supported by the Swedish Science Council and KaroBio AB.

\section{References}

Blaak E 2001 Gender differences in fat metabolism. Current Opinion in Clinical Nutrition and Metabolic Care 4 499-502.

Bray GA 2002 The underlying basis for obesity: relationship to cancer. Fournal of Nutrition 132 3451S-3455S.

Cao G, Beyer TP, Yang XP, Schmidt RJ, Zhang Y, Bensch WR, Kauffman RF, Gao H, Ryan TP, Liang Y, Eacho PI \& Jiang XC 2002 Phospholipid transfer protein is regulated by liver X receptors in vivo. Fournal of Biological Chemistry 277 39561-39565.

Chen HC \& Farese RV Jr 2001 Turning WAT into BAT gets rid of fat. Nature 7 1102-1103.

Chomczynski P \& Sacchi N 1987 Single-step method of RNA isolation by acid guanidinium thiocyanate-phenol-chloroform extraction. Analytical Biochemistry 162 156-159.

Collins S, Cao W, Daniel KW, Dixon TM, Medvedev AV, Onuma H \& Surwit R 2001 Adrenoceptors, uncoupling proteins, and energy expenditure. Experimental Biology and Medicine 226 982-990.

Costet P, Luo Y, Wang N \& Tall AR 2000 Sterol-dependent transactivation of the $\mathrm{ABCl}$ promoter by the liver $\mathrm{X}$ receptor/retinoid X receptor. Fournal of Biological Chemistry 275 28240-28245.

Crandall DL, Busler DE, Novak TJ, Weber RV \& Kral JG 1998 Identification of estrogen receptor beta RNA in human breast and 
abdominal subcutaneous adipose tissue. Biochemical and Biophysical Research Communications 248 523-526.

Dixon TM, Daniel KW, Farmer SR \& Collins S 2001 CCAAT/enhancer-binding protein alpha is required for transcription of the beta 3-adrenergic receptor gene during adipogenesis. Fournal of Biological Chemistry 276 722-728.

Eckel RH 1989 Lipoprotein lipase. A multifunctional enzyme relevant to common metabolic diseases. New England Fournal of Medicine 320 1060-1068.

Edwards PA, Kennedy MA \& Mak PA 2002 LXRs; oxysterol-activated nuclear receptors that regulate genes controlling lipid homeostasis. Vascular Pharmacology 38 249-256.

Faust IM, Johnson PR, Stern JS \& Hirsch J 1978 Diet-induced adipocyte number increase in adult rats: a new model of obesity. American Fournal of Physiology 235 E279-E286.

Flodby P, Barlow C, Kylefjord H, Ahrlund-Richter L \& Xanthopoulos KG 1996 Increased hepatic cell proliferation and lung abnormalities in mice deficient in CCAAT/enhancer binding protein alpha. Fournal of Biological Chemistry 271 24753-24760.

Geary N 2001 Estradiol, CCK and satiation. Peptides 22 1251-1263.

Haslam SZ \& Shyamala G 1981 Relative distribution of estrogen and progesterone receptors among the epithelial, adipose, and connective tissue components of the normal mammary gland. Endocrinology 108 825-830.

Heine PA, Taylor JA, Iwamoto GA, Lubahn DB \& Cooke PS 2000 Increased adipose tissue in male and female estrogen receptor-alpha knockout mice. PNAS 97 12729-12734.

Homma H, Kurachi H, Nishio Y, Takeda T, Yamamoto T, Adachi K, Morishige K, Ohmichi M, Matsuzawa Y \& Murata Y 2000 Estrogen suppresses transcription of lipoprotein lipase gene. Existence of a unique estrogen response element on the lipoprotein lipase promoter. Fournal of Biological Chemistry 275 11404-11411.

Hunt SM \& Clarke CL 1999 Expression and hormonal regulation of the Sox 4 gene in mouse female reproductive tissues. Biology of Reproduction 61 476-481.

Jimenez M, Leger B, Canola K, Lehr L, Arboit P, Seydoux J, Russell AP, Giacobino JP, Muzzin P \& Preitner F 2002

$\operatorname{Beta}(1) /$ beta(2)/beta(3)-adrenoceptor knockout mice are obese and cold-sensitive but have normal lipolytic responses to fasting. FEBS Letters 530 37-40.

Jones DR, Schmidt RJ, Pickard RT, Foxworthy PS \& Eacho PI 2002 Estrogen receptor-mediated repression of human hepatic lipase gene transcription. Fournal of Lipid Research 43 383-391.

Jones ME, Thorburn AW, Britt KL, Hewitt KN, Wreford NG, Proietto J, Oz OK, Leury BJ, Robertson KM, Yao S \& Simpson ER 2000 Aromatase-deficient (ArKO) mice have a phenotype of increased adiposity. PNAS 97 12735-12740.

Joseph SB, Laffitte BA, Patel PH, Watson MA, Matsukuma KE, Walczak R, Collins JL, Osborne TF \& Tontonoz P 2002 Direct and indirect mechanisms for regulation of fatty acid synthase gene expression by liver X receptors. Fournal of Biological Chemistry 277 11019-11025.

Juvet LK, Andresen SM, Schuster GU, Dalen KT, Tobin KA, Hollung K, Haugen F, Jacinto S, Ulven SM, Bamberg K, Gustafsson JÅ \& Nebb HI 2003 On the role of liver x receptors in lipid accumulation in adipocytes. Molecular Endocrinology 17 $172-182$

Kersten S 2001 Mechanisms of nutritional and hormonal regulation of lipogenesis. EMBO Reports 2 282-286.

Kramer PR \& Wray S 2002 17-Beta-estradiol regulates expression of genes that function in macrophage activation and cholesterol homeostasis. Fournal of Steroid Biochemistry and Molecular Biology 81 203-216.

Kuczmarski RJ, Flegal KM, Campbell SM \& Johnson CL 1994 Increasing prevalence of overweight among US adults. National
Health and Nutrition Examination Surveys, 1960 to 1991. Foumal of the American Medical Association 272 205-211.

Laffitte BA, Repa JJ, Joseph SB, Wilpitz DC, Kast HR, Mangelsdorf DJ \& Tontonoz P 2001 LXRs control lipid-inducible expression of the apolipoprotein $\mathrm{E}$ gene in macrophages and adipocytes. PNAS 98 507-512.

Langhans W 2002 Peripheral mechanisms involved with catabolism. Current Opinion in Clinical Nutrition and Metabolic Care 5 419-426.

Langin D, Holm C \& Lafontan M 1996 Adipocyte hormone-sensitive lipase: a major regulator of lipid metabolism. Proceedings of the Nutrition Society 55 93-109.

Langin D, Lucas S \& Lafontan M 2000 Millennium fat-cell lipolysis reveals unsuspected novel tracks. Hormone and Metabolic Research 32 443-452.

Levin-Allerhand J, McEwen BS, Lominska CE, Lubahn DB, Korach KS \& Smith JD 2001 Brain region-specific up-regulation of mouse apolipoprotein E by pharmacological estrogen treatments. Fournal of Neurochemistry 79 796-803.

Liang G, Yang J, Horton JD, Hammer RE, Goldstein JL \& Brown MS 2002a Diminished hepatic response to fasting/refeeding and liver $\mathrm{X}$ receptor agonists in mice with selective deficiency of sterol regulatory element-binding protein-1c. Fournal of Biological Chemistry 277 9520-9528.

Liang YQ, Akishita M, Kim S, Ako J, Hashimoto M, Iijima K, Ohike Y, Watanabe T, Sudoh N, Toba K, Yoshizumi M \& Ouchi Y $2002 b$ Estrogen receptor beta is involved in the anorectic action of estrogen. International Journal of Obesity and Related Metabolic Disorders 26 1103-1109.

Lincova D, Misekova D, Elisova K \& Wenke M 1984 Effect of oestradiol on catecholamine-stimulated lipolysis. Physiologia Bohemoslovaca 33 342-352.

Linhart HG, Ishimura-Oka K, DeMayo F, Kibe T, Repka D, Poindexter B, Bick RJ \& Darlington GJ 2001 C/EBPalpha is required for differentiation of white, but not brown, adipose tissue. PNAS 98 12532-12537.

Liu G, Loraine AE, Shigeta R, Cline M, Cheng J, Valmeekam V, Sun S, Kulp D \& Siani-Rose MA 2003 NetAffx: Affymetrix probesets and annotations. Nucleic Acids Research 31 82-86.

Mandrup S \& Lane MD 1997 Regulating adipogenesis. Fournal of Biological Chemistry 272 5367-5370.

Mizutani T, Nishikawa Y, Adachi H, Enomoto T, Ikegami H, Kurachi H, Nomura T \& Miyake A 1994 Identification of estrogen receptor in human adipose tissue and adipocytes. fournal of Clinical Endocrinology and Metabolism 78 950-954.

Mueller SO \& Korach KS 2001 Estrogen receptors and endocrine diseases: lessons from estrogen receptor knockout mice. Current Opinion in Pharmacology 1 613-619.

Naaz A, Zakroczymski M, Heine P, Taylor J, Saunders P, Lubahn D \& Cooke PS 2002 Effect of ovariectomy on adipose tissue of mice in the absence of estrogen receptor alpha (ERalpha): a potential role for estrogen receptor beta (ERbeta). Hormone and Metabolic Research 34 758-763.

Nadler ST, Stoehr JP, Schueler KL, Tanimoto G, Yandell BS \& Attie AD 2000 The expression of adipogenic genes is decreased in obesity and diabetes mellitus. PNAS 97 11371-11376.

Navre M \& Ringold GM 1989 Differential effects of fibroblast growth factor and tumor promoters on the initiation and maintenance of adipocyte differentiation. Fournal of Cell Biology 109 $1857-1863$.

Nilsson S, Makela S, Treuter E, Tujague M, Thomsen J, Andersson G, Enmark E, Pettersson K, Warner M \& Gustafsson JÅ 2001 Mechanisms of estrogen action. Physiological Reviewes $\mathbf{8 1}$ $1535-1565$.

Ogawa S, Chan J, Gustafsson JÅ, Korach KS \& Pfaff DW 2003 Estrogen increases locomotor activity in mice through estrogen receptor alpha: specificity for the type of activity. Endocrinology 144 230-239. 
Ohlsson C, Hellberg N, Parini P, Vidal O, Bohlooly M, Rudling M, Lindberg MK, Warner M, Angelin B \& Gustafsson JA 2000 Obesity and disturbed lipoprotein profile in estrogen receptor-alpha-deficient male mice. Biochemical and Biophysical Research Communications 278 640-645.

Palin SL, McTernan PG, Anderson LA, Sturdee DW, Barnett AH \& Kumar S 200317 beta-estradiol and anti-estrogen ICI:compound 182,780 regulate expression of lipoprotein lipase and hormone-sensitive lipase in isolated subcutaneous abdominal adipocytes. Metabolism 52 383-388.

Parini P, Angelin B \& Rudling M 1997 Importance of estrogen receptors in hepatic LDL receptor regulation. Arteriosclerosis, Thrombosis, and Vascular Biology 17 1800-1805.

Pedersen SB, Bruun JM, Hube F, Kristensen K, Hauner H \& Richelsen B 2001 Demonstration of estrogen receptor subtypes alpha and beta in human adipose tissue: influences of adipose cell differentiation and fat depot localization. Molecular and Cellular Endocrinology 182 27-37.

Pettersson K, Grandien K, Kuiper GG \& Gustafsson JA 1997 Mouse estrogen receptor beta forms estrogen response element-binding heterodimers with estrogen receptor alpha. Molecular Endocrinology 11 1486-1496.

Poehlman ET 2002 Menopause, energy expenditure, and body composition. Acta Obstetricia et Gynecologica Scandinavica 81 603-611.

Price TM \& O'Brien SN 1993 Determination of estrogen receptor messenger ribonucleic acid (mRNA) and cytochrome P450 aromatase mRNA levels in adipocytes and adipose stromal cells by competitive polymerase chain reaction amplification. Fournal of Clinical Endocrinology and Metabolism 77 1041-1045.

Prins JB \& O'Rahilly S 1997 Regulation of adipose cell number in man. Clinical Science $\mathbf{9 2} 3-11$.

Repa JJ, Liang G, Ou J, Bashmakov Y, Lobaccaro JM, Shimomura I, Shan B, Brown MS, Goldstein JL \& Mangelsdorf DJ 2000 Regulation of mouse sterol regulatory element-binding protein-lc gene (SREBP-1c) by oxysterol receptors, LXRalpha and LXRbeta. Genes and Development 14 2819-2830.

Rosen ED \& Spiegelman BM 2000 Molecular regulation of adipogenesis. Annual Review of Cell and Developmental Biology 16 $145-171$.

Schultz JR, Tu H, Luk A, Repa JJ, Medina JC, Li L, Schwendner S, Wang S, Thoolen M, Mangelsdorf DJ, Lustig KD \& Shan B 2000 Role of LXRs in control of lipogenesis. Genes and Development $\mathbf{1 4}$ 2831-2838.

Seiki K, Imanishi Y \& Haruki Y 1978 Accumulation and binding of $3 \mathrm{H}$-estradiol- 17 beta by lymphoid tissues of castrated mice. Endocrinologia faponica 25 289-294.

Shimomura I, Bashmakov Y \& Horton JD 1999 Increased levels of nuclear SREBP-1c associated with fatty livers in two mouse models of diabetes mellitus. Fournal of Biological Chemistry $\mathbf{2 7 4}$ 30028-30032.

Somjen D, Tordjman K, Waisman A, Mor G, Amir-Zaltsman Y, Kohen F \& Kaye AM 1997 Estrogen stimulation of creatine kinase B specific activity in 3T3 L1 adipocytes after their differentiation in culture: dependence on estrogen receptor. Fournal of Steroid Biochemistry and Molecular Biology 62 401-408.

Soukas A, Socci ND, Saatkamp BD, Novelli S \& Friedman JM 2001 Distinct transcriptional profiles of adipogenesis in vivo and in vitro. Fournal of Biological Chemistry 276 34167-34174.

Steffensen KR, Schuster GU, Parini P, Holter E, Sadek CM, Cassel T, Eskild W \& Gustafsson JA 2002 Different regulation of the
LXRalpha promoter activity by isoforms of

CCAAT/enhancer-binding proteins. Biochemical and Biophysical Research Communications 293 1333-1340.

Stulnig TM, Steffensen KR, Gao H, Reimers M, Dahlman-Wright K, Schuster GU \& Gustafsson JA 2002 Novel roles of liver X receptors exposed by gene expression profiling in liver and adipose tissue. Molecular Pharmacology 62 1299-1305.

Tchernof A, Calles-Escandon J, Sites CK \& Poehlman ET 1998 Menopause, central body fatness, and insulin resistance: effects of hormone-replacement therapy. Coronary Artery Disease 9 503-511.

Tomita T, Yonekura I, Okada T \& Hayashi E 1984 Enhancement in cholesterol-esterase activity and lipolysis due to 17 beta-estradiol treatment in rat adipose tissue. Hormone and Metabolic Research 16 525-528.

Ulloa N, Arteaga E, Bustos P, Duran-Sandoval D, Schulze K, Castro G, Jauhiainen M, Fruchart JC \& Calvo C 2002 Sequential estrogen-progestin replacement therapy in healthy postmenopausal women: effects on cholesterol efflux capacity and key proteins regulating high-density lipoprotein levels. Metabolism $\mathbf{5 1}$ 1410-1417.

Usui S, Suzuki K, Yamanaka H, Nakano T, Nakajima K, Hara Y \& Okazaki M 2002 Estrogen treatment of prostate cancer increases triglycerides in lipoproteins as demonstrated by HPLC and immunoseparation techniques. Clinica Chimica Acta $\mathbf{3 1 7}$ 133-143.

Venkateswaran A, Repa JJ, Lobaccaro JM, Bronson A, Mangelsdorf DJ \& Edwards PA 2000 Human white/murine ABC8 mRNA levels are highly induced in lipid-loaded macrophages. A transcriptional role for specific oxysterols. Fournal of Biological Chemistry 275 14700-14707.

Viguerie N, Millet L, Avizou S, Vidal H, Larrouy D \& Langin D 2002 Regulation of human adipocyte gene expression by thyroid hormone. Fournal of Clinical Endocrinology and Metabolism $\mathbf{8 7}$ 630-634.

Wade GN \& Gray JM 1978 Cytoplasmic 17 beta-[3H]estradiol binding in rat adipose tissues. Endocrinology 103 1695-1701.

Wade GN \& Gray JM 1979 Gonadal effects on food intake and adiposity: a metabolic hypothesis. Physiology and Behaviour 22 583-593.

Wang ND, Finegold MJ, Bradley A, Ou CN, Abdelsayed SV, Wilde MD, Taylor LR, Wilson DR \& Darlington GJ 1995 Impaired energy homeostasis in C/EBP alpha knockout mice. Science $\mathbf{2 6 9}$ 1108-1112.

Yamaguchi M, Katoh S, Morimoto C, Sakayama K, Shiosaka T, Masuno H \& Okuda H 2002 The hormonal responses of lipoprotein lipase activity and lipolysis in adipose tissue differ depending on the stage of the estrous cycle in female rats. International Fournal of Obesity and Related Metabolic Disorders 26 610-617.

Zhang Y, Repa JJ, Gauthier K \& Mangelsdorf DJ 2001 Regulation of lipoprotein lipase by the oxysterol receptors, LXRalpha and LXRbeta. Fournal of Biological Chemistry 276 43018-43024.

\section{Received 26 January 2004 \\ Accepted 16 February 2004 \\ Made available online as an \\ Accepted Preprint 3 March 2004}

